Nives Dolšak*

\title{
Bowling Together: Mobilization of Collective Action by Environmental NGOs
}

DOI 10.1515/npf-2016-0025

\begin{abstract}
Social capital generated by frequent, face-to-face interactions provides the foundation for collective action. Does this also hold for a community action in post-communist, Central European countries where modern NGOs are perceived to be ineffective? This article examines this question in the context of the cleanup of illegal dumpsites organized by a Slovenian NGO, Ecologists without Borders, in 2010. This community cleanup effort sought to produce local public goods such as improved aesthetics, sanitation, and ground water quality. Local participation levels (percentage of adults contributing to the cleanup effort) varied across 192 districts of Slovenia. Analyzing an original, micro-level dataset, this article finds that, all else equal, social capitals rooted in frequent faceto-face interactions (the common Catholic religion and membership in Hunters clubs) are associated with increased participation levels. However, social capital generated via common native language does not show statistical association with participation levels.
\end{abstract}

Keywords: social capital, collective action, post-communist civil society, environmental NGOs

\section{Introduction}

On April 17, 2010, Ekologi Brez Meja, Ecologists without Borders (EWB), a Slovenian environmental NGO, organized a cleanup of illegal dumpsites across Slovenia. This cleanup was expected to produce local public goods such as improved aesthetics, sanitation, and ground water quality. Because cleaning up is a labor-intensive process, EWB, an organization with limited number of formal members, sought to mobilize local citizens via various civil society- and other types of networks. It employed its marketing skills to widely publicize the event and ensured media coverage. The social mobilization for the clean-up efforts was impressive: the overall participation levels stood at $15 \%$ of the adult population. Yet, this mobilization varied from $0 \%$ to $40 \%$ across 192 districts of

*Corresponding author: Nives Dolšak, School of Marine and Environmental Affairs, University of Washington, 3707 Brooklyn Ave NE, Seattle, WA 98195-5350, USA, E-mail: nives@uw.edu 
Slovenia. Drawing on the scholarship that emphasizes the important role of social capital rooted in regular face-to-face interactions in facilitating communitarian action, this article examines how variations in the strength of different types of social capitals explain this district-level variation in volunteer participation.

This article contributes to two important debates in the nonprofit literature. First, scholars debate the strength of civil society (or nongovernmental organizations, NGOs) in the transitional economies of Eastern and Central Europe. Some warn of its limited effectiveness (Howard 2003; Fagan 2005; Fagan and Sircar 2016) because, as they see it, the modern NGO sector lacks local support and therefore does not have the capacity for grassroots mobilization (Carmin and Fagan 2010; Fagan and Carmin 2011). Others present a more encouraging picture. For them, civil society strength should not be assessed by examining their formal membership only (Leskinen 2015; Krasynska 2015). NGOs with limited membership can be effective if they are able to build networks with multiple organizations (Cisař 2010; Jacobsson and Saxonberg 2016) to successfully foster "transactional activism" (Petrova and Tarrow 2007). This article contributes to the above debates by examining how a modern environmental NGO, Ekologi Brez Meja (Ecologist without borders), with a limited membership, succeeded in organizing a nation-wide environmental clean-up event in Slovenia by collaborating with traditional NGOs, governmental agencies, and for-profit organizations.

Civil society faces many challenges in organizing collective action, such as incentives to free ride. NGOs mobilize social action because they draw on social capital. Social capital refers to "norms and networks that enable collective action. It encompasses institutions, relationships, and customs that shape the quality and quantity of a society's social interactions."1 The second debate this article contributes to centers around how different types of social capitals might influence social mobilization and social action. Because traditional civil society groups can represent different types of social capital, the paper asks if the cleanup was more successful when local groups reflected specific types of social capital. To examine this question, the article presents a statistical study examining variation of local participation levels (percentage of adults participating in the cleanup) across 192 districts of Slovenia. Analyzing an original, micro-level dataset, it finds that, all else equal, social capitals rooted in frequent face-to-face

\footnotetext{
$1 \mathrm{http}: / /$ web.worldbank.org/WBSITE/EXTERNAL/TOPICS/EXTSOCIALDEVELOPMENT/ EXTTSOCIALCAPITAL/0, contentMDK:20642703 menuPK:401023 pagePK:148956 piPK:216618 theSitePK:401015,00. html; February 5, 2014.
} 
interactions (the common Catholic religion and membership in Hunters clubs) are associated with increased participation levels. However, social capital generated via common native language does not show statistical association with participation levels.

Social capital is a widely researched concept in social sciences (Coleman 1988; Putnam, Leonardi, and Nanetti 1993; Knack and Keefer 1997; Woolcock 1998; Kwon and Adler 2014). ${ }^{2}$ Scholars note that social capital promotes the norm of reciprocity and generates inter-personal trust, thereby allowing individuals to transact in situations of incomplete contracting (Ostrom 1990). At the level of an individual, social capital can enhance productivity of individuals as economic, political or social agents. At the level of a community, by mitigating free riding, social capital can facilitate collective action.

Yet, social capital has multiple dimensions because individuals are embedded in different types of social relationships. These ties can be generated through mechanisms such as membership in social groups, shared religion, and language. Scholars suggest that not all ties work in the same fashion. For example, some ties build social cohesion by allowing individuals to surmount social cleavages while others accentuate them by strengthening social ties within the group (such as common religion or common language) but at the cost of lower cohesion across groups (Putnam 2000). An important lesson is that different types of social capitals should not be assumed to have the same ability to facilitate community efforts and social action.

How to think of civil society groups and the social capitals they draw on in the context of transitional societies of Easter and Central Europe? Scholars employ various terms to describe this sector: civil society organizations, the third-sector, the voluntary sector, NGOs, non-profit, etc. (Vakil 1997). Typically, scholars focus on four types of organizations: (1) advocacy NGOs that seek to influence public policy; (2) non-profit, service delivery organizations that are funded by donors to provide "merit goods" to the underprivileged; (3) hobby groups ${ }^{3}$ that provide local level club goods (Putnam 2000); and (4) community groups that seek sustainable use of local common-pool resources (Ostrom 1990). In the context of transitional societies of Eastern and Central Europe, the author views the first two, advocacy and nonprofit groups, as "modern" civil society sector. They tend to be of recent origin, established primarily after 1990. These groups typically do not secure most

2 For a critique of the concept of social capital.

3 Surprisingly, I find the literature on hobby organizations as representing the modern NGO sector to be underdeveloped. Further, I do find evidence that private foundations or intergovernmental organizations are actively promoting hobby organizations in their civil society or third sector initiatives. 
of their resources from their members or the communities they serve. Instead, they rely on donors (foundations, domestic and foreign governments, and intergovernmental organizations) for their resource needs.

Scholars such as Putnam (2000) and Ostrom (1990) focus on small community groups be it the Bowling Leagues or small user communities seeking to sustainably use local level common pool resources. Both of these types tend to have frequent face-to-face interactions. In contrast, the modern NGO sector often does not involve individuals whose livelihoods are dependent on a natural resource or who mobilize their resources locally such as via membership dues. Modern groups also vary in the frequency of their members' face-toface interactions. If the strength of social ties depends on the regularity and frequency of interaction, the social capital(s) generated via interactions in the modern advocacy NGO sector might be weaker in relation to traditional community groups, both secular and religious. While modern NGO groups have a comparative advantage in marketing, publicity, and translating global norms into local public policy, the author suggests that they can successfully mobilize local population only if they form alliances with traditional, grassroots groups. As is shown here, the mobilization success of a modern advocacy group (Ecologists Without Borders) was significantly facilitated by a wellestablished, locally rooted secular hobby group (Hunters Club) as well as religious organization (Catholic Church). Using a novel district-level data set of local ties in Slovenia, the article finds that social capitals generated via secular "hobby" groups as well as through shared religion are positively correlated with mobilization success. Importantly, these social ties also involve regular face-to-face interaction. On the other hand, social capital generated through a common language did not show statistically significant association with local participation. In contrast to the previous two ties, common language, while providing a sense of a shared identity, does not involve regular face-to-face interactions. While secular-religious social capital or bonding-bridging social capital dichotomies do not explain these results, this work suggests that the frequency of face-to-face interactions might help us understand this puzzle. Thus, this article supports the emphasis scholars have placed on face-to-face interactions in fostering social ties, leading to local level collective action.

The article proceeds as follows. In section 2, it provides a short discussion on how social ties create different types of social capitals that influence collective action. In section 3, it introduces the case study and describes how EWB sought to organize district level clean-up efforts. In section 4, it presents the variables, models, statistical analyses, and findings. The conclusions are presented in section 5 . 


\section{Social Capital and Community Action}

Different disciplines study social action by non-state, non-market actors and often place them under different labels (Vakil 1997; Johnson and Prakash 2007). Sociologists and political scientists study activism by NGOs, activist networks, and social movements to shape public policy (Tarrow 1998; Keck and Sikkink 1998). Other scholars study nonprofits that supply goods and services. Nonprofits are distinguished by their unique institutional structure; the nondistributional constraint (Hansmann 1980). In addition to NGOs and nonprofits, yet another literature studies hobby groups and community efforts to provide local public goods or club goods. While Putnam (2000) focused, inter alia, on community groups such as bowling leagues, which bring together citizens with shared interests, Ostrom's (1990) work focused on the communitarian efforts by user groups for sustainable use of resources.

Alexis de Tocqueville's ([1840] 1945) book, Democracy in America noted the importance of associational activity in American politics and society. Since Tocqueville, several scholars have documented contributions of community groups in the social, economic and political processes across countries. In recent decades, Coleman (1988) in sociology and Putnam, Leonardi, and Nanetti (1993) in political science, produced systematic and careful work on the emergence and deployment of social capital. The phrase "social capital" has two components, social and capital. Capital - financial, physical, human, or social - pertains to assets that create future benefits for capital owners. Asset creation typically involves forgoing benefits emanating from these investments today in order to capture a larger stream of benefits in the future. It involves making choices between short-term sacrifice and risk-adjusted long-term gains.

The "social" aspect of social capital refers to its emergence due to social interactions and the fact that it resides in social ties. ${ }^{4}$ As with any capital, social capital requires individuals to make valuable investments in social ties. ${ }^{5}$ These investments could be in form of time or tangible resources. Social ties lead to repeated interactions. This creates inter-personal trust, which can help individuals in a range of tasks. Trust, the belief that other actors in the transaction will honor their commitments, generated in one set of interactions can sometimes spill over to other interactions (Putnam, Leonardi, and Nanetti (1993); Fukuyama 1995). Because many social transactions are based on incomplete contracting, fearing opportunism including free riding and shirking, individuals may not

4 For a debate on the concept of social trust see Dasgupta and Serageldin (1999).

5 Some dispute this: For them, social capital emerges from routine interactions and does not require investments which forgo current consumption (Arrow 1999). 
enter into these transactions. Alternatively, they may invest valuable resources to unproductive or suboptimal task such as buying "insurance" to protect themselves from ex post opportunism. While social capital might emanate from routine interactions, it can entail valuable payoffs in the future.

According to Ostrom and Ahn (2008), the concept of social capital has important implications for understanding collective action. Olson (1965), a first generation collective action theorist as per Ostrom and Ahn, challenged the assertion that individuals with common interests will tend to act together to pursue common interests. Olson noted that if group action creates non-excludable benefits which can be appropriated by all, then individuals can have incentives to free-ride on efforts of others. To mitigate free riding, organizations must provide excludable, selective benefits. Ostrom (1990) notes that the temptations to free ride can be mitigated by social ties. This is because the social ties in which they are embedded can generate trust, allowing individuals to rein in their incentives to free-ride and contribute to collective endeavors in the expectation that others would do the same.

The mechanism through which social capital impacts collective action is the generation of inter-personal trust. Putnam, Leonardi, and Nanetti (1993) showed how the differences in densities of social ties between the regions of Northern Italy and Southern Italy explain variations in their economic performance. The crucial point is that social ties developed in even routine social interactions can generate inter-personal trust whose effects can sometimes spillover beyond these interactions. Given the situation of incomplete contracting and potential for free-riding opportunities, these social ties provide the assurance that other parties in the social interaction will rein in their opportunism and the individual will not be faced with a sucker's payoff.

So far this article has suggested that social ties generate inter-personal trust. But would these lead to the development of generalized trust that allows individuals to trust others who are not in their social group? What types of ties create in-group cohesion, thereby strengthening social cleavages, and what types of ties incentivize individuals to surmount these cleavages? This is a debated subject in the social capital literature. Putnam (2000) differentiates between bridging and bonding social capital. The former pertains to "social ties that link people together with others across a cleavage that typically divides society (like race, or class, or religion)" while the latter pertains to "social ties that link people together with others who are primarily like them along some key dimension." 6 Thus, some types of social capitals enhance intra-group harmony but fuel inter-group tension. They support the "us versus them" mentality, which undermines the broader social cohesion.

6 http://www.hks.harvard.edu/saguaro/glossary.htm; accessed February 5, 2014. 
What is crucial is that an individual might be embedded in different social networks promoting different types of social ties. Thus, one must recognize multiple dimensions of social capital without assuming that all dimensions are equally significant for an individual in a given "action situation" (Ostrom 1990), or incentivize this individual to contribute to collective action in the same way. Thus, while social capital can enhance inter-personal trust and enhance the prospects for collective action, this article suggests looking at different types of social capitals and examining how they enhance or even impede different types of collective action. For example, in communal activities involving the production of local public goods that require participation of people with different types of social ties, bridging social capital will enhance local participation but bonding social capital might reduce it. Or, instead of the bridging versus bonding divide, we should look for the frequency of face-to-face interactions in understanding the efficacy of different types of social capital.

As is discussed in the next section, types of social ties that generate social capital have an important bearing on explaining participation in community action to clean up illegal dumpsites. This article finds that some types of social capital played an important role while others did not. Importantly, these variations in the efficacy of different types of social capitals cannot be explained by the traditional distinction between bridging and bonding social capital. Instead, we need to focus on social capital rooted in frequent face-to-face interactions as opposed to social capital generated by a common identity only. This article suggests that it is the face-to-face interactions that allow for local mobilization for the provision of local public goods.

\section{Cleaning Up Illegal Dumpsites: The Slovenian Case}

Slovenia is a transitional economy in Central Europe. It was a part of the former Yugoslavia and attained independence in 1991. Slovenia joined the European Union in 2004. Given its high per capita income (about \$30,000 in 2014) it is a member of the Organization for Economic Cooperation and Development. Yet, Slovenia like other Central European countries is transitioning society with an uneven development of its civil society sector (Dolšak and Prakash 2013; Mondak and Gearing 1998; Baker and Jehlička 1998; Bădescu, Sum and Uslaner 2004; Howard 2003). It is often assumed that under the communist rule, any collective action outside the communist party was actively discouraged and the truly autonomous civil society was replaced by 
“compulsory pseudo-associations” (Kolakowski 1971, 41). ${ }^{7}$ Demonstrating that social ties helped communitarian action in a transitional economy can be viewed as a hard case to test the efficacy of social capital.

However, civil society was not entirely absent in European communist countries (Leskinen 2015). Slovenia had some fairly established secular civil society groups such as hunters clubs. It also has an active Catholic church that was allowed to function during the communist era. Importantly, the distinguishing feature of Slovenia is its language, not ethnicity. Hence, both religion and language are an important source of social identity. Yet as this article shows, shared identity by itself may not suffice for local mobilization; it must be accompanied by frequent face to-face-interactions.

As in most transitional economies, the modern NGO sector, specifically, the advocacy NGOs and nonprofits, is on the rise in Slovenia. These NGOs tend to rely on foreign support (foundations, governments, inter-governmental organizations) and not on financial contributions from their members (Fagan 2002; Henderson 2003). While in some transitional economies, NGOs' legitimacy and power in the 1980s lay in anti-regime protests, in the new era, the modern NGOs have needed to learn how to oppose specific policies as well as collaborate with the government on other issues. Importantly, if they seek to mobilize local population for specific tasks as opposed to limiting themselves to policy advocacy, they need to engage with traditional groups whose relative advantage is their grass-roots support base.

This article examines local participation in the provision of local public good via cleanup of illegal dumpsites. The clean-up project is a trans-world movement. It started in 2008 in the Baltic countries of Estonia, Lithuania, and Latvia. Since 2008, about 16 million volunteers have engaged in clean-up projects across countries, now called "Let's do it World". ${ }^{8}$ Participation levels have varied substantially across countries. In 2010, Slovenia, with almost $15 \%$ participating level held the record, followed by Latvia with $10.5 \%$, Sweden with $7.4 \%$, and Lithuania with $7.0 \% .^{9}$

In Slovenia, the clean-up project was started in 2009 by a small modern NGO, Ecologists without Borders (EWB). These activists followed the Estonian approach. When Nara Petrovič, one of the founding members of EWB, attended a conference in Finland in summer of 2009, he learned about the Estonian project. He shared a video about the 2008 Estonian efforts with his Slovenian friends and asked whether this could be replicated in Slovenia. Inspired by the

7 For an opposing view, see Krasynska (2015) and Leskinen (2015).

8 http://www.letsdoitworld.org/. Accessed, February 4, 2017.

9 http://www.letsdoitworld.org/. Accessed, January 4, 2014. 
Estonian example, a group of environmental activists established EWB in the fall of 2009. Thus, the core idea to clean up illegal dumpsites emerged abroad. The transnational linkages among environmental activists afforded Nara Petrovič the opportunity to learn about this effort, which he, along with his friends, replicated in his home country. This is an excellent example of policy diffusion here it is via the agency of non-governmental actors - and the role transnational networks play in this regard.

EWB formed working groups and established a list of volunteers with their specific skills. Although a young organization, it recognized the importance of grassroots mobilization to accomplish this task. It also recognized that it did not have the grassroots infrastructure to accomplish its goals. It therefore adopted two strategies. First, instead of hiring a paid workforce for the cleanup, it decided to organize local community level action. Second, it understood the need to involve established, traditional NGOs and government agencies. In some ways, EWB's strategies resemble what Ostrom (1996) has termed as co-production of public goods and what Petrova and Tarrow (2007) called transactional activism - the combined efforts of both government and nongovernmental actors working together to produce collective goods.

To elaborate on the collaboration process, EWB involved a range of actors including schools, waste collection companies, and local governments. It involved local churches and reached out to traditional civil society groups. The Slovenia Forestry Service, aided by the police and the army, agreed to map all illegal dumpsites in Slovenian forests. Further, seeking to exploit its expertise in modern marketing tools, EWB hired a firm to develop a logo, and a website enabling citizens to report illegal dumpsites. In January 2010, EWB presented the clean-up project to the Association of Municipalities of Slovenia and secured the support of key politicians across the political spectrum, including the Prime Minister and the President. This was also the time when the media began covering their efforts. By February 2010, EWB had documented about 10,000 illegal dumpsites.

The Slovenian clean-up project "Očistimo Slovenijo" (Let's clean up Slovenia) took place on April 17, 2010. This was a single-day event. Local government helped in the coordination of efforts in each district and waste disposal firms removed collected waste. In total, 194,000 adults, 15\% of the adult population ${ }^{10}$ participated in this effort and cleaned up about 7,000 illegal dumpsites. However, the clean-up efforts exhibited large variations across 192 districts in Slovenia, as depicted in Figure 1.

$10 \mathrm{http} / / / 2012$. ocistimo.si/Rezultati-projekta-Ocistimo-Slovenijo-v-enem-dnevu.aspx. Accessed on December 16, 2013. 


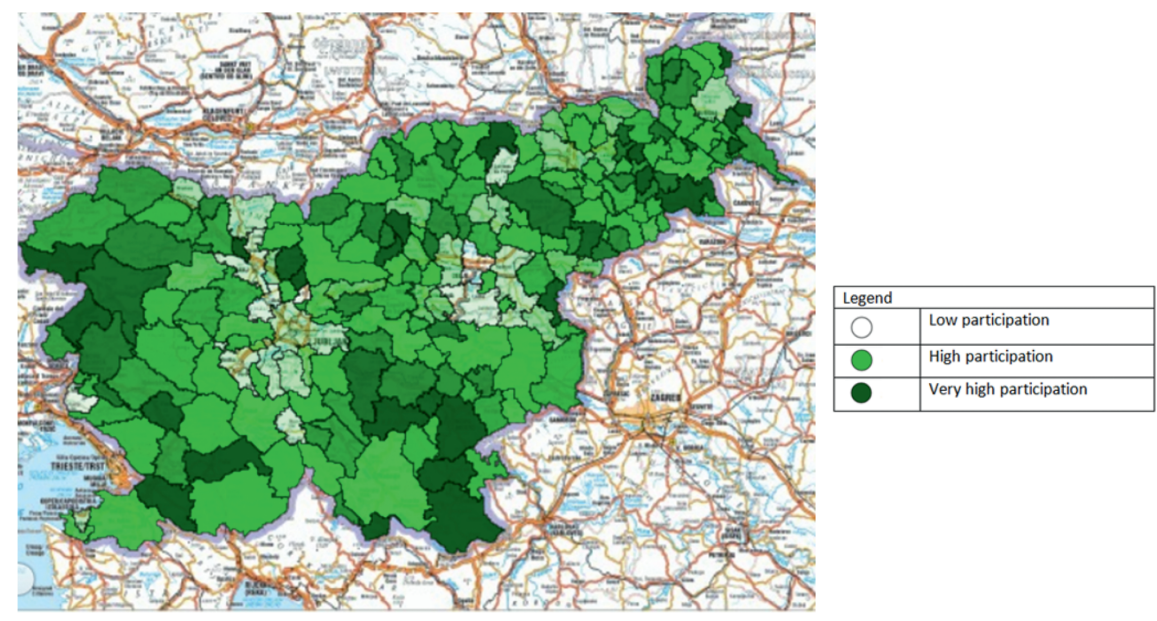

Figure 1: Number of participants in the 2010 clean-up (by district - "Občina”).

Source: http://www.geopedia.si/?params = T1558\#T1558_x499072_y112072_s8_b4

What explains variation in participation levels across districts? Typically, the modern NGO sector is supposed to be the strongest in urban areas. Interestingly, areas around two large cities, Ljubljana, the capital city, and Celje (lying northeast of Ljubljana), exhibited the lowest levels of participation.

As indicated earlier in the article, this cleanup was aimed at producing local public goods such as improved sanitation, aesthetics, and ground water quality. Illegal dumpsites have been identified as an important ecological problem of Slovenia. ${ }^{11}$ While legal waste dumpsites follow the EU Directive on Integrated Pollution Prevention and Control for proper treatment of water runoff and gas emissions from these sites, illegal dumpsites cause multiple problems. They become breeding sites for carriers of infectious diseases (mosquitos and rodents). Waste paints, motor oils, and other liquid pollutants contaminate surface and running water. ${ }^{12}$ Much of waste emanates from the construction industry (Smrekar 2007). Given the decentralized nature of this industry, which makes monitoring difficult, coupled with resource scarcity at the district government level, which also makes monitoring difficult, these sites have proliferated. $^{13}$

11 www.stat.si/PDF/eng/PrikaziPDF.aspx?ID = 3059; accessed February 5, 2014.

12 http://www.ipep.gov.si/fileadmin/ipep.gov.si/pageuploads/IRSOP_dokumenti/dokumenti_ 10/INFORMACIJE_O_STANJU_DIVJA_ODLAGALISCA.pdf accessed on November 9, 2013. 13 Ibid. 
How did EWB, a modern NGO of a recent vintage, encourage grassroots mobilization? Interestingly, even during the communist era, some traditional community groups concerned with environmental protection were active. Because they did not seek political mobilization under the garb of environmental protection, the communist state did not suppress their activities. ${ }^{14}$ In particular, the role of Hunters Club is important in the clean-up efforts. This club was established in $1907 .{ }^{15}$ While this is a hobby group for hunters - arguably even more established than Putnam's famous Bowling Leagues - it encourages its members to protect the environment. Hunting is popular activity in Slovenia; for reference Slovenia has $58 \%$ of its land area under forest; only Sweden and Finland are ahead of Slovenia in this regard. ${ }^{16}$ Thus, environmental protection coheres with the mission of these clubs that bring together Slovenian citizens who enjoy hunting. EWB targeted such groups with a presence in every district of Slovenia. This shows how a modern NGO recognized and worked with traditional community groups for grass-roots mobilization.

\section{Model, Variables, and Findings}

\section{Model and Variables}

This article employs regression analysis to examine the relationship between social capital and district level participation in cleanup of illegal dumpsites. The unit of analysis is a district (equivalent to a U.S. county). There are 210 districts in Slovenia. Data are available for 192 districts that are included in the analysis. Given that the dependent variable is continuous, an ordinary least square (OLS) regression model is employed to estimate regression coefficients. The model is specified as:

Percent Adult Participation $=\alpha+\beta_{1}$ social capital $+\beta_{2}$ illegal dumpsites $+\beta_{3}$ tourism $+\beta_{4}$ monthly salary $+\varepsilon$

Participation level is measured as percent of adults participating in the cleanup in each district. Data on district-wise raw participation numbers are available from EWB (2011). Because population counts in districts vary, participation level is

14 http://ribiska-zveza.si/o-nas/zgodovina accessed, December 7, 2013.

15 http://www.lovska-zveza.si/default.aspx?MenuID = 61, accessed, February 1, 2014.

16 http://www.vlada.si/en/about_slovenia/geography/forests_in_slovenia/; accessed February 1, 2014. 
normalized by dividing participation counts by mid-year population in each district in 2010. Population data are from the Statistical Office of Republic of Slovenia (SORS). ${ }^{17}$ As noted in the Descriptive Statistics (Table 1), participation levels show considerable variations, ranging from less than $1 \%$ of adults to $40 \%$.

Table 1: Range of variation in variables.

\begin{tabular}{lrr}
\hline Variable & Min & Max \\
\hline Adults' Participation in Clean-up Activities (\% of population) & 0 & 40.06 \\
Catholics (\% of population) & 14.05 & 91.04 \\
Hunters (per 1,000 population) & 0 & 146 \\
Hunting clubs (per 1,000 population) & 0 & 2.49 \\
Slovenian mother tongue (\% of population) & 34.83 & 98.27 \\
Illegal dumpsites (per km ${ }^{2}$ area) & 0 & 4.17 \\
Tourism (Overnight stays/per 1,000 population) & 0 & $106,067.20$ \\
Monthly gross salary (in $€$ ) & 734.66 & $1,856.59$ \\
\hline
\end{tabular}

$\mathrm{N}=192$.

Social capital is measured in three ways: shared religious values, shared native language, and the strength of a key community group with interest in environmental protection. The shared religious values are operationalized as percent of self-declared Catholics in each district (as per 2002 census). ${ }^{18}$ Slovenia is predominantly a Catholic country. Even during the communist rule, churches were allowed to function and devout citizens, although discouraged, were able to participate in various activities of the church. Thus, the Catholic Church is an important source of inter-personal ties and affords numerous opportunities to its members to engage face-to-face. A common faith tends to serve as the social glue. As is common in most Slovenian towns and villages, the ringing of the Church bell several times a day marks not only the daily schedule and events, but reminds everybody of their faith and values. Indeed, Tocqueville had also commented on the important role of religion in America's social life ([1840] 1945). While Slovenia is predominantly a Catholic country, the share of Catholics varies across districts: from $14 \%$ to $91 \%$. If religious ties create a bonding social capital, then religious heterogeneity will depress participation levels in the clean-up effort.

17 http://www.stat.si/obcine/sl/2010/Theme/Index/PrebivalstvoSplosno. Accessed on January 7, 2014.

$18 \mathrm{http}: / /$ www.stat.si/popis2002/si/rezultati/rezultati_red.asp?ter $=$ OBC\&st $=6$ Accessed on January 14, 2014. 
Scholars note the role of language in fostering understanding of shared rules. There is some work that suggests that common language is a predictor of the strength of social ties (Putnam 2000) while others find that this concept does not apply in the European context (Gesthuizen, Van Der Meer, and Scheepers 2008). The language issue is quite salient in Slovenia that is primarily a linguistic entity. Historically, the shared language has differentiated Slovenians from other southern Slavs such as Croats and Serbs. Indeed, even during the communist period, Slovenia was recognized as a distinct republic within Yugoslavia. While linguistic nationalism was actively discouraged by the Communists, governmental and educational activities in Slovenia were conducted in Slovenian language. The importance of Slovenian language in building a common identity considerably strengthened since Slovenia seceded from Yugoslavia in 1991. The model, therefore, includes the percent of population in each district declaring Slovenian as their mother tongue (as per 2002 census). ${ }^{19}$ This variable shows considerable variation across districts: the share of population declaring Slovenian as the native language varies from $34 \%$ to $98 \%$. While shared language facilitates the evolution of a common identity, it does not necessarily facilitate frequent, face-to-face social interactions. And even if it creates social capital, it is the bonding type. If so, linguistic heterogeneity will depress participation levels.

The third dimension of social capital considered here is the number of hunting clubs (per thousand residents) and number of hunters (per thousand residents). ${ }^{20}$ Community groups that allow individuals to come together frequently to pursue common interests, the Bowling leagues in Putnam's work, strengthen social ties. If these groups also directly or indirectly seek to protect the environment, their members will have strong incentives to join the clean-up activity. The Hunting Association of Slovenia (Lovska Zveza Slovenije) is among the oldest and most active community organizations in Slovenia. The Hunting Association of Slovenia was founded in 1907. Its key goals include sustainable management of wildlife, education of hunters about a variety of issues related to hunting such as environmental protection, issuance of hunting permits, participation in research related to wildlife and hunting, and communication with landowners and the public about hunters and hunting. ${ }^{21}$ To account for possible annual variations in its membership, an average membership over three years

$19 \mathrm{http} / /$ www.stat.si/popis2002/si/rezultati/rezultati_red.asp?ter $=$ OBC\&st $=2$ Accessed on January 14, 2014.

20 The author thanks Srečko Žerjav, Director of Professional Services, the Hunting Association of Slovenia, for data on membership in hunting clubs in years 2008-2010.

21 http://www.lovska-zveza.si/?MenuID = 72 Accessed, February 4, 2014. 
preceding the clean-up (2008-2010) is used. This variable shows considerable variation across districts; from 0 to 146 hunters (per thousand residents) or from 0 to 2.5 hunting clubs (per thousand residents).

In addition to the three types of social capitals that are the key independent variables, the model controls for other factors that might impact the success of community efforts to manage shared natural resources. Collective action might be facilitated if the problem is severe. Suppose a pastoral community depends on the health of the pasture land to sustain its livestock. If this pasture land is under severe ecological strain, the community might be more amenable to collectively take measures to address this problem. Hence, the model controls for problem severity by including the number of illegal dumpsites in each district, identified by EWB prior to the clean-up project. Given that larger districts might have more dumpsites, the number of illegal dumpsites is normalized by the area of the district.

Collective action might be facilitated if actors see direct economic benefits from their actions. Illegal dumpsites make areas less attractive to tourists; tourism is a major industry in Slovenia. The direct and indirect impact of tourism accounts for about $8.5 \%$ of its GDP. ${ }^{22}$ Tourists tend to visit Slovenia to enjoy its natural beauty as opposed to say its architectural masterpieces. For districts that are frequently visited by tourists, the removal of illegal dumpsites increases their attractiveness to tourists. While tourists visiting only for a day are less likely to explore the area, tourists staying overnight are more likely to spend extended time in the area, and are, therefore, more likely to come across an illegal dumpsite. Therefore, the model controls for the number of overnight stays by tourists in each district ${ }^{23}$ divided by 1,000 residents of the district.

There is some evidence that wealthier households have a greater ability to participate in social events. On the other hand, economically underprivileged are less able to participate in social events, hobby clubs, or PTA meetings simply because the opportunity cost of such participation tends to be high. Hence, levels of social capital tend to be higher in richer areas. Therefore, the model controls for gross monthly salary of individuals employed in each district. ${ }^{24}$

22 http://www.stat.si/novica_prikazi.aspx?id = 5247 Accessed, February 10, 2014.

$23 \mathrm{http} / /$ pxweb.stat.si/pxweb/Dialog/varval.asp? $\mathrm{ma}=$ 2164408S\&ti $=$ Prihodi + in + preno $\%$ E8itve + turistov + po + dr\% $\%$ Eavah $\% 2 \mathrm{C}+$ ob $\%$ E8ine $\% 2 \mathrm{C}+$ Slovenija $\% 2 \mathrm{C}+$ mese $\%$ E8no\&path $=. . /$ Database/Ekonomsko/21_gostinstvo_turizem/01_21644_nastanitev_mesecno/\&lang = 2 Accessed, February 7, 2014.

24 http://www.stat.si/obcine/sl/2010/Theme/Index/PrebivalstvoSplosno Accessed on December 17, 2013. 


\section{Findings}

The results of the regression analysis are presented in Table 2. Five models are estimated. These models present different operationalizations of the key variable of interest, social capital. ${ }^{25}$ The first model includes the measure of core value/ religious homogeneity (percent of catholic population). The second model includes shared Slovenian native language as the measure of social capital.

Table 2: OLS regression coefficient for participation of adults (as \% of population) in clean-up activities.

\begin{tabular}{|c|c|c|c|c|c|}
\hline Variable & Model 1 & Model 2 & Model 3 & Model 4 & Model 5 \\
\hline $\begin{array}{l}\text { Catholics (\% of } \\
\text { population) }\end{array}$ & $\begin{array}{l}0.07398^{\star} \\
(0.04246)\end{array}$ & & & & $\begin{array}{r}0.03113^{\dagger} \\
(0.04149)\end{array}$ \\
\hline $\begin{array}{l}\text { Hunters (per } 1,000 \\
\text { population) }\end{array}$ & & & $\begin{array}{r}0.10782^{\star \star \star} \\
(0.02227)\end{array}$ & & $\begin{array}{r}0.10391^{\star \star *}+ \\
(0.02290)\end{array}$ \\
\hline $\begin{array}{l}\text { Hunting clubs (per } \\
1,000 \\
\text { population) }\end{array}$ & & & & $\begin{array}{r}4.90748^{\star \star *} \\
(1.29025)\end{array}$ & \\
\hline $\begin{array}{l}\text { Slovenian mother } \\
\text { tongue (\% of } \\
\text { population) }\end{array}$ & & $\begin{array}{l}-0.01953 \\
(0.05547)\end{array}$ & & & \\
\hline $\begin{array}{l}\text { Illegal dumpsites } \\
\text { (per km² area) }\end{array}$ & $\begin{array}{l}-1.14109 \\
(0.81212)\end{array}$ & $\begin{array}{r}-1.44560^{\star} \\
(0.80071)\end{array}$ & $\begin{array}{l}-0.55229 \\
(0.77650)\end{array}$ & $\begin{array}{l}-0.73338 \\
(0.79318)\end{array}$ & $\begin{array}{l}-0.45990 \\
(0.78709)\end{array}$ \\
\hline $\begin{array}{l}\text { Tourism (Overnight } \\
\text { stays/per } 1,000 \\
\text { population) }\end{array}$ & $\begin{array}{l}0.00006^{\star} \\
(0.00003)\end{array}$ & $\begin{array}{l}0.00005^{\star} \\
(0.00003)\end{array}$ & $\begin{array}{l}0.00005^{\star} \\
(0.00003)\end{array}$ & $\begin{array}{r}0.00005 \\
(0.00003)\end{array}$ & $\begin{array}{l}0.00005^{\star} \\
(0.00003)\end{array}$ \\
\hline $\begin{array}{l}\text { Monthly gross } \\
\text { salary (in €) }\end{array}$ & $\begin{array}{l}-0.00321 \\
(0.00351)\end{array}$ & $\begin{array}{l}-0.00438 \\
(0.00352)\end{array}$ & $\begin{array}{l}-0.00183 \\
(0.00333)\end{array}$ & $\begin{array}{l}-0.00225 \\
(0.00340)\end{array}$ & $\begin{array}{l}-0.00149 \\
(0.00336)\end{array}$ \\
\hline
\end{tabular}

$\mathrm{N}=192 ;$ Standard errors in parentheses.

${ }^{*} \alpha \leq 0.10$

${ }^{* \star} \alpha \leq 0.05$

${ }^{* \star *} \alpha \leq 0.01$

$+\alpha \leq 0.001$ (joint test)

25 Multicollinearity does not present a problem for the various measures of social capital employed here. I employ two tests of the extent of multicollinearity recommended by Berry and Feldman (1985). First, the matrix of binary correlation coefficients indicates only correlation between the two measures of the strength of hunting hobby organizations (hunters per thousand population and number of hunting clubs per thousand population; correlation coefficient of 0.89 ). All other social capital measures have binary correlation coefficients of 0.42 or lower. Second, regressing each measure of social capital on all other independent variables (testing for multicolinearity beyond binary correlation) produces $\mathrm{R}^{2}$ values of 0.26 or lower, again suggesting that multicolinearity is not a concern here. 
The third model includes number of hunters per thousand residents as a measure of social capital. The fourth uses number of hunting clubs per thousand residents as an indicator of social capital. The last model includes both religion and hunters, the two measures of social capital with statistically significant regression coefficients.

The results provide support for the hypothesized role of some types of social capital in inducing local participation for the clean-up efforts. Two out of three measures of social capital, religion and the strength of the traditional hobby club (measured either as number of hunters or hunter clubs) are statistically significant. Both types of social capital are rooted in frequent, face-to-face interactions among community members. Impact of the shared native language is not statistically significant. Arguably, this is a surprising finding given the important role of Slovenian language in Slovenia's social and political life. Yet, common language does not necessarily lead to face-to-face interactions that can build deep social ties. Perhaps, linguistic ties are less important when the collective action pertains to the issues within the community. They might be important when collective action pertains to issues of "us" versus "them".

When included in the analysis individually, both the share of Catholics (Model 1) and the number of hunters (or hunting clubs) (Models 3 and 4) are statistically significant. A 10 percent point increase in the share of Catholics is associated with 0.7 percent point increase in participation levels, all else equal. An increase of 10 hunters/1,000 residents is associated with about 1 percent point increase in participation levels, all else equal. Further, an increase of 1 hunting club per 1,000 residents is associated with an almost 5 percent point increase in participation, all else equal. When both shared religion and hunting clubs are included in the model, they are both jointly statistically significant. Therefore, these results provide some evidence that two types of social capitals generated through common religion and membership in a common hobby group (hunting) - are associated with increased participation levels in the community efforts to clean-up illegal dumpsites. In conclusion, when examining the relationships between social capital and collective action, one has to look at specific types of social capitals (in plural), rather than social capital (in singular) in general. Some types of social capital may be more fungible than others.

\section{Conclusions}

This paper has important policy implications for thinking about the role of NGOs in the transitional societies. As I find in the paper, some sort of civil society existed in several transitional countries even during the communist rule. The 
new and modern civil society organizations need to finds ways to collaborate with these traditional organizations. There is a literature that speaks to the dualism in the civil society sector where the "modern" NGO sector co-exists with the traditional civic groups but overtime the former seems to be the displacing the latter (Chahim and Prakash 2014). Yet, the modern sector typically does not have the deep roots and social embeddedness to organize largescale social action. This article suggests that possibility of organizing large-scale social action is increased when modern NGOs with their relative advantage in marketing and publicity are able to join hands with traditional groups who have established institutionalized mechanisms for social mobilization. Overseas donors (both governmental organizations and large foundations) have tended to neglect local groups, especially locally hobby groups. There is also a tendency to shy away from funding religious groups. This paper suggests that this sort of approach needs to be revisited if donors want civil society actors to mobilize the community for specific projects.

This article also speaks to the literature on communist legacy underlining the challenges in the development of civil society in former communist countries (Michnik 1998; Tucker 2000; Howard 2003; Fagan and Carmin 2011). It suggests that social capital can be important for collective endeavors even in societies with communist legacies. In part, countries have had varying experiences regarding how the communist party treated community organizations outside the party. In the Yugoslavian experience, the party tolerated the Catholic Church and hobby groups such as hunters clubs. The Yugoslavian communist party also allowed its "republics" to conduct governmental work and education in their own languages. Hence, language and religion became a source of strong social ties but of the bonding variety. Yet, they had important differences: social ties via religion were strengthened by regular face-to-face interaction while language provided a shared identity only. Hence, religion is a more potent form of social capital for organizing communitarian efforts.

Future work should examine how social capital created by nationalism or shared ethnicity, history, or language, differs from one that is rooted in face-toface interactive activities. Arguably, while language can help develop a shared identity, it does not necessarily provide incentives for face-to-face activity. While the identity-based bonding capital might be useful in the mobilization of "us" versus "them", it seems to be less useful in mobilizing "us" for tasks that do not bear on core issues of identity politics. Future work should seek to develop more sophisticated categories of social capital, or suggest contingency theories that help us understand conditions under which different types of social capital even within a given subcategory - might motivate collective action. This study has some obvious limitations in terms of generalizability. It is limited to one country 
and examines a one-shot event. While this focus has enabled a statistical analysis with the micro-level data, generalizability of the finding to other contexts needs to be established, not assumed. These results need to be validated in terms of other events requiring communitarian action to assess the level to which insights from the study of "illegal dumpsites cleanup" can illuminate them.

Face-to-face interactions can take place in a variety of settings. In the context of this paper, face-to-face interactions took place within a highly institutionalized setting, which allowed mitigating collective action problems in organizing social action (Sampson et al. 2005). A highly institutionalized setting perhaps also has a history of facilitating social action in some other context. Thus, there is probably also some sort of institutional knowledge at work on how to mobilize members for a given social task. Arguably, high frequency faceto-face interactions in a less institutionalized setting where the rules of interactions are less defined (meeting same set of people during the evening walk, for example) would probably be less successful in organizing social action, an issue future research should examine.

Finally, while I do not find the bonding-bridging dichotomy useful in explaining motivation for social action, as opposed to the frequency of face-to-face interaction, it is quite possible that bonding-bridging dichotomy is analytically useful in other types of situations. Think of the success of ethnic or religious organizations for identity-focused causes, even in the absence of high frequency face-to-face interactions. Thus, the effectiveness of various types of social capitals in mobilizing social action needs to be understood in specific contexts.

\section{References}

Arrow, K. 1999. “Observations on Social Capital.” In Social Capital: A Multifaceted Perspective, edited by P. Dasgupta and I. Serageldin. Washington, DC: The World Bank.

Baker, S. and P. Jehlička. 1998. "Dilemmas of transition: The environment, democracy and economic reform in East Central Europe - an Introduction”. Environmental Politics 7 (1):1-26.

Bădescu, G., P. Sum, and E. M. Uslaner. 2004. "Civil Society Development and Democratic Values in Romania and Moldova”. East European Politics and Societies 18 (2):316-341.

Berry, W.D., and S. Feldman. 1985. Multiple Regression in Practice. Thousand Oaks: Sage Publications, Inc.

Carmin, J., and A. Fagan. 2010. "Environmental Mobilization and Organisations in Post-Socialist Europe and the Former Soviet Union.” Environmental Politics 19 (5):589-707.

Chahim, D. and A. Prakash. 2014. "NGOization, Foreign Funding, and the Nicaraguan Civil Society”. Voluntas, 25 (2):487-513.

Cisař, 0. 2010. "Externally Sponsored Contention: The Channelling of Environmental Movement Organisations in the Czech Republic after the Fall of Communism." Environmental Politics 19 (5):736-755. 
Coleman, J. 1988. "Social Capital in the Creation of Human Capital." American Journal of Sociology 94 (supplement):S95-S120.

Dasgupta, P., and I. Serageldin. 1999. Social Capital: A Multifaceted Perspective. Washington, DC: The World Bank.

Dolšak, N. 2013. "Climate Change Policies in the Transitional Economies of Europe and Eurasia." Voluntas 24 (2):382-402.

Dolšak, N. and A. Prakash. 2017. "Join the Club: How the Domestic NGO Sector Induces Participation in the Covenant of Mayors Program”. International Interactions 43 (1):26-77.

Ecologists without Borders Association. 2011. Očistimo Slovenijo v enem dnevu. Final Report. Assembled and composed by Nara Petrovič, translated by Nara Petrovič, Jaka Kranjc. Ecologists without Borders Association, 2011. Accessed January 4, 2014. http://ebm.si/r/ OSVED-zakljucno.si.pdf.

Fagan, A. 2002. "The Czech Republic." In Capacity Building in National Environmental Policy: A Comparative Study of 17 Countries, edited by H. Weidner and M. Jänicke, 177-200. New York: Springer.

Fagan, A. 2005. "Taking Stock of Civil-Society Development in Post-Communist Europe: Evidence from the Czech Republic." Democratization 12 (4):528-547.

Fagan, A., and J. Carmin, eds. 2011. Green Activism in Post-Socialist Europe and the Former Soviet Union. London: Routledge.

Fagan, A., and I. Sircar. 2016. "Environmental Movement Activism in the Western Balkans: Evidence from Bosnia-Herzegovina." In Beyond NGO-Ization: The Development of Social Movements in Central and Eastern Europe, edited by K. Jacobsson and S. Saxonberg. New York: Routledge Press.

Fukuyama, F. 1995. Trust: The Social Virtues and the Creation of Prosperity. New York: Free Press. Gesthuizen, M., T. Van Der Meer, and P. Scheepers. 2008. "Ethnic Diversity and Social Capital in Europe: Tests of Putnam's Thesis in European Countries." Scandinavian Political Studies 32 (2):121-142.

Hansmann, H.B. 1980. “The Role of Nonprofit Enterprise.” Yale Law Review 89:835-898.

Henderson, S. 2003. Building Democracy in Contemporary Russia: Westernsupport for Grassroots Organizations. Ithaca: Cornell University Press.

Howard, M.M. 2003. The Weakness of Civil Society in Post-Communist Europe. New York: Cambridge University Press.

Jacobsson, K., and S. Saxonberg, eds. 2016. Beyond NGO-Ization: The Development of Social Movements in Central and Eastern Europe. New York: Routledge Press.

Johnson, E. and A. Prakash. 2007. "NGO Research Program: A Collective Action Perspective". Policy Sciences 40 (3):221-240.

Keck, M.E., and K. Sikkink. 1998. Activists beyond Borders: Advocacy Networks in International Politics. Ithaca, N.Y.: Cornell University Press.

Knack, S., and P. Keefer. 1997. "Does Social Capital Have an Economic Pay Off? A Cross-Country Investigation." Quarterly Journal of Economics 112:1251-1288.

Kolakowski, L. 1971. “Hope and Hopelessness.” Survey 17 (3):37-52.

Krasynska, S. 2015. "Contra Spem Spero: The Third Sector's Resilience in the Face of Political Turbulence and Legislative Change in Ukraine." Nonprofit Policy Forum 6 (2):167-186.

Kwon, S.-W., and P. Adler. 2014. "Social Capital: Maturation of a Field of Research." Academy of Management Review 39 (4):412-422.

Leskinen, A. 2015. "Methodological Issues in Studies of Cultural Legacies in Post-Socialist Russia’s Civil Society." Nonprofit Policy Forum 6 (2):145-165. 
Michnik, A. 1998. Letters from Freedom: Post-Cold War Realities and Perspectives. Berkeley: University of California Press.

Mondak, J. J. and A. F. Gearing. 1998. "Civic Engagement in a Post-Communist State." Political Psychology 19 (3):615-637.

Olson, M. 1965. The Logic of Collective Action. Cambridge: Harvard University Press.

Ostrom, E. 1996. “Crossing the Great Divide: Coproduction, Synergy and Development." World Development 24 (6):1073-1087.

Ostrom, E. 1990. Governing the Commons. New York: Cambridge University Press.

Ostrom, E., and T.K. Ahn. 2008. "The Meaning of Social Capital and Its Links to Collective Action." In Handbook on Social Capital, edited by G.T. Svendsen and G.L. Svendsen, 17-35. Northampton, MA: Edward Elgar.

Petrova, T., and S. Tarrow. 2007. "Transactional and Participatory Activism in the Emerging European Polity: The Puzzle of East Central Europe." Comparative Political Studies 40 (1):74-94.

Putnam, R. 2000. Bowling Alone: The Collapse and Revival of American Community. New York: Simon and Schuster.

Putnam, Robert, with Robert Leonardi and Raffaella Nanetti. 1993. Making Democracy Work. Princeton, NJ: Princeton University Press.

Sampson, R.J., D. Mcadam, H. MacIndoe, and S. Weffer-Elizondo. 2005. "Civil Society Reconsidered: The Durable Nature and Community Structure of Collective Civic Action." American Journal of Sociology 111 (3):673-714.

Smrekar, A. 2007. Divja odlagališča odpadkov na območju Ljubljane (Illegal waste dumps in the Ljubljana area). Geografski Inštitut Antona Melika, Ljubljana.

Tarrow, S.G., ed. 1998. Power in Movement: Social Movements and Contentious Politics, 2nd ed. Cambridge and New York: Cambridge University Press.

Tocqueville, A.D. [1840] 1945. Democracy in America. New York: Alfred A. Knopf.

Tucker, A. 2000. The Philosophy and Politics of Czech Dissidence from Patočka to Havel. Pittsburgh: University of Pittsburgh Press.

Vakil, A.C. 1997. “Confronting the Classification Problem: Toward a Taxonomy of Ngos." World Development 25 (12):2057-2070.

Woolcock, M. 1998. "Social Capital and Economic Development: Toward a Theoretical Synthesis and Policy Framework." Theory and Society 27 (2):151-208. 